\title{
Original
}

\section{Effect of the Neuraminidase Purified from Prevotella loescheii on Hemagglutination by Porphyromonas gingivalis}

Porphyromonas gingivailis の赤血球凝集反応に 及ぼす Prevotella loescheii より精製された ノイラえニダーゼの影響

Tetsuo TAKESHITA*, Katsuko IWAKURA*,
Masaru TAKAGAKI*, Takashi HANIOKA*,
Hiroo TAMAGAWA ${ }^{*}$ and Satoshi SHIZUKUISHI
竹下 哲 生* 岩 倉 功 ${ }^{*}$ 高 垣 勝
埴 岡 隆 ${ }^{*}$ 玉 川 裕 夫* 零 石 聰*

Received June 24, 1991 ; accepted September 2, 1991

\begin{abstract}
概要: Porphyromonas gingivalis の赤血球凝集機棲に関与するシアル酸の役割について追究するため, Prevotella loesheii より精製したノイラミニダーゼを用いて，P. gingivalis の赤血球凝集反応に及ぼす精製ノイ ラミニダーゼの影響について検討した。ヒトO型赤血球を精製酵素で処理して，マイクロタイタープレート を用いた連続 2 倍希䣋法で P. gingivalis の赤血球凝集活性を測定したところ，アシアロ赤血球（血球表面 の糖タンパク犋よりシアル酸を取り除いた赤血球）にするとP. gingivalis の赤血球凝集能が增大した。次 いで，分光光度計による赤血球凝集活性測定法により，P. gingivalis 381 株の赤血球疑集能に及ぼす種々の 因子について追究した。P. gingivalis 381株菌体の赤血球凝集活性は，正常赤血球，アシアロ赤血球いずれ も，供試した糖やアミノ酸では阻害を受けなかった。また，サルミン, cGMP 依存性キナーゼ阻害因子，フ ンジオテンシンI， II および且のよらなアルギニンを含むぺプチドでは 正常赤血球ならびにアシアロ赤血球 に対して，程度に差はあるが，凝集の阻害がみられたが，サルミンは双方の赤血球に対し低溜度で凝集を特 異的に阻害した。次いで，正常赤血球表面よりシアル酸を精製醅素で除去した際，赤血球表面の荷電状鸷の 変化を調べるために，正常赤血球およびアシアロ赤血球表面のゼータ電位を測定した。その結果。正常赤血 球のゼーダ電位はー $18.3 \pm 3.10 \mathrm{mV}$ であったが, アシアロ赤血球のゼータ電位はー4.4 $1.16 \mathrm{mV}$ と著明に変 動した。さらに，酵素量を変化させて，赤血球表面より段階的にシアル酸を除去したところ，赤血球からの 遊離シアル酸量が增大するにつれて, 赤血球表面のゼータ電位は 0 值に近うき, かつ, P. gingivalis 381株菌 体の赤血球凝集活性は增大する傾向を示した。以上の結果より，本菌とアシアロ赤血球との疑集能が，正常 赤血球と比へて増大する現象には，赤血球表面のゼータ電位の低下が密接に関与していることが明らかにな
\end{abstract}

* Department of Preventive Dentistry, Osaka University Faculty of Dentistry (Chief: Prof. Akira TSUNEMITSU)

* 大阪大学歯学部予防㐘科学教室（主任: 常光 旭教授） 
った。

\section{Koy words: Neuraminidase, Hemagglutination, Zeta potential}

索引用語：ノイラミニダーゼ，赤血球凝集活性，ゼータ電位

\section{Introduction}

Sialic acid is a component of carbohydrate chains in various glycoproteins such as salivary glycoproteins, serum glycoproteins, and glycoproteins of cell membranes. In studies on salivary-bacterial interactions $^{1,2)}$, the removal of sialic acid residues of various salivary glycoproteins, such as mucin and other bacterial agglutinins, diminished their interactions with Streptococcus sanguis and Streptococcus mitis. In contrast, the abilities of Actinomyces strains to cause hemagglutination and to bind to epithelial cells were enhanced by removing sialic acid from erythrocytes $(\mathrm{RBCs})^{3,4)}$ and epithelial cell $s^{5}$. Thus, the presence or absence of sialic acid residues in glycoproteins appears to influence interactions between sialoglycoproteins and bacteria in the oral cavity. Porphyromonas gingivalis, which has been demonstrated to increase in subgingival dental plaque samples of human periodontal lesions ${ }^{6}$, can agglutinate $\mathrm{RBC}$ s and bind to sulcular epithelium and saliva-coated hydroxyapatite ${ }^{7)}$. However, it has not been determined whether sialic acid residues in glycoconjugates are involved in interactions between $P$. gingivalis and host surfaces.

Neuraminidase (EC 3.2.1.18) cleaves $\alpha$-ketosidic linkages between $N$-acetylneuraminic acid (NANA) and the remaining carbohydrate chains of oligosaccharides, glycolipids and glycoproteins. Activity of neuraminidase in the oral cavity has been found in dental plaque ${ }^{8)}$, in salivary secretions ${ }^{93}$, and in crevicular fluid ${ }^{10)}$. Several investigators demonstrated that neuraminidase was present in the culture supernatant of some oral streptococci11,12). Previously we sought the presence of neuraminidase in culture supernatant and cell sediment from 29 strains of oral anaerobic bacteria which are believed to be intimately related to periodontal disease. Strong activity of neuraminidase was found in the culture medium of Prevotella loe$s c h e i i^{13)}$, and the neuraminidase was purified ${ }^{14)}$. In this study, we examined the effect of purified neuraminidase-treatment of RBCs on hemagglutination by $P$. gingivalis.

\section{Materials and Methods}

Bacterial strains and growth conditions

The strains of black-pigmented anaerobic rods used in this study were obtained from the Research Laboratory of Oral Biology, Sunstar Inc., Osaka, Japan. All strains were maintained on plates containing Trypticase soy agar (BBL Microbiology System, Cockeysville, MD) supplemented with $5 \%$ sheep blood; yeast extract (BBL), $1 \mathrm{mg} / \mathrm{m} l$; hemin, $5 \mu \mathrm{g} / \mathrm{m} l$; and menadione, $1 \mu \mathrm{g} / \mathrm{m} l$. The strains of black-pigmented anaerobic rods were grown in $100 \mathrm{~m} l$ of Trypticase soy broth (BBL) supplemented with yeast extract, 1 $\mathrm{mg} / \mathrm{m} l$; hemin $5 \mu \mathrm{g} / \mathrm{m} l$; menadione $1 \mu \mathrm{g} / \mathrm{m} l$. Cultures were incubated in an Anaerobic System 1024 (Forma, Marietta, $\mathrm{OH})$ in an atmosphere of $\mathrm{N}_{2}-\mathrm{H}_{2} \cdot \mathrm{CO}_{2}(80: 10: 10)$.

Purification of neuraminidase

The neuraminidase was purified from the culture medium of $P$. loescheii ATCC 15930, as described previously ${ }^{14)}$.

Hemagglutination assay

The cells of black-pigmented anaerobic rods used here were harvested from the culture, washed three times by centrifugation at $10,000 \times \mathrm{g}$ for $20 \mathrm{~min}$ in $10 \mathrm{mM}$ phosphate- $0.15 \mathrm{M} \mathrm{NaCl}, \mathrm{pH} 7.0$ (PBS), and suspended in the same buffer to an optical density of 1.0 at $660 \mathrm{~nm}$. Human O-type RBCs were washed three times by centrifugation at $1,000 \times \mathrm{g}$ for $5 \mathrm{~min}$ in PBS and were used within 2 days of collection. 
Neuraminidase-treatment of washed RBCs was performed by incubation with $10 \mathrm{~m} l$ of $10 \%$ (vol/vol) packedcell suspension in $10 \mathrm{mM}$ acetate- $0.15 \mathrm{M} \mathrm{NaCl}$ buffer, pH 5.5 and 0.5 unit of the purified neuraminidase for $60 \mathrm{~min}$ at $37^{\circ} \mathrm{C}$. One unit of enzyme was defined as the amount which releases $1 \mu \mathrm{mol}$ of NANA per min, as measured by Uchida et al.15).

A visual assay was performed at room temperature with a microtiter plate (Linbro Division Flow Laboratories Inc., Hamden, CONN). Serial dilutions of bacterial cell suspensions were mixed with equal volumes of $2 \% \mathrm{RBC}$ suspensions. The mixtures were left to stand for $60 \mathrm{~min}$, and hemagglutination was determined by observing the mixture without magnification. Titer was expressed as the reciprocal of the highest dilution showing positive agglutination.

Hemagglutination of $P$. gingivalis was also followed by a turbidimetric method. The progress of hemagglutination was monitored by the absorbance at $542 \mathrm{~nm}\left(\mathrm{~A}_{542}\right)$ for $15 \mathrm{~min}$ at $37^{\circ} \mathrm{C}$ using a UV-visible recording spectrophotometer and a temperature-controlled cuvette compartment with a magnetic stirrer (UV-265 FW, Shimadzu). Suspensions of about $5 \times 10^{7}$ of $\mathrm{RBC}$ and about $3 \times 10^{8}$ bacterial cells were mixed with $10 \mathrm{mM}$ PBS ( $\mathrm{pH} 7.0$ ) or inhibitor to a total volume of $2 \mathrm{ml}$ in a cuvette. The hemagglutinating activity was defined as the difference in optical density at $542 \mathrm{~nm}$ between 0 time and 10 min after starting the reaction.

Determination of zeta potential

The method for preparation of $\mathrm{RBC}$ and bacterial suspensions was the same as that described for the turbidimetric method of hemagglutination. The zeta potentials were determined from electrophoretic mobilities by means of a Lazer-zee meter Model 501 (Pen-Kem, Inc., Bedford Hills, NY), which automatically incorporates the conductivity of the suspension and is based on the application of the Smoluchowski equation ${ }^{16)}$. The voltage used was $100 \mathrm{~V}$. The electrophoretic mobility of each sample was measured 10 times at $37^{\circ} \mathrm{C}$

\section{Results}

The hemagglutinating titers of black-pigmented anaerobic rods using neuraminidase-treated and untreated $\mathrm{RBCs}$ are shown in Table 1. $P$. gingivalis strains tested had strong hemagglutinating activity

Table 1 Hemagglutinating titer of black-pigmented anaerobic rods for the purified neuraminidase-treated and untreated RBCs

\begin{tabular}{llcc}
\hline \multirow{2}{*}{ Species and strain } & \multicolumn{2}{c}{ Hemagglutinating titer for* } \\
\cline { 3 - 4 } & & Native RBCs & $\begin{array}{c}\text { Neuraminidase-treated } \\
\text { RBCs }\end{array}$ \\
\hline P. gingivalis & 381 & 128 & 512 \\
& Sun-3 & 128 & 512 \\
& ATCC 33277 & 256 & 1024 \\
P. intermedia & ESS-1 & 256 & 1024 \\
P. denticola & ATCC 25261 & 2 & 8 \\
B. levii & ATCC 33185 & 2 & 16 \\
14015 & JP-2-77 & 2 & 8 \\
loescheii & ATCC 15930 & 0 & 0 \\
\hline
\end{tabular}

* Titer was expressed as the reciprocal of the highest dilution showing positive agglutination on a microtiter plate. 


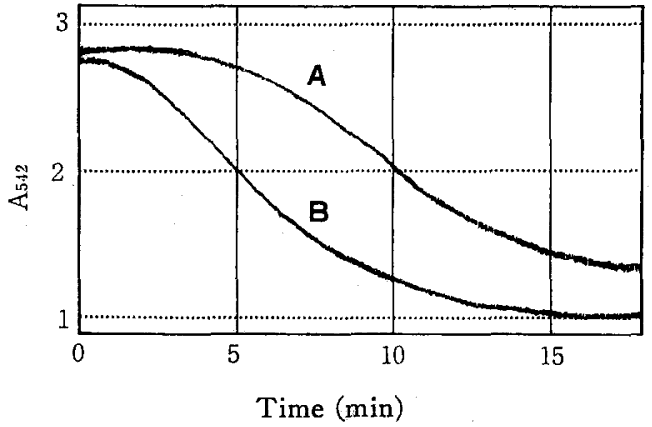

Fig. 1 Hemagglutination reactions with $P$. gingivalis cells and either the native $\mathrm{RBCs}$ (A) or neuraminidase-treated $\mathrm{RBCs}$ (B) by continuous recording of turbidity measurements. and the strains of Prevotella intermedia and Prevotella denticola showed weak activity. The ability of these organisms to hemagglutinate was strongly enhanced by neuraminidase-treatment of the RBCs. However, strains of Bacteroides levii and $P$. loescheii agglutinated neither neuraminidase-treated nor untreated RBCs.

The representative curves shown in Fig. 1 are actual recorder tracings for the hemagglutination reactions of the neuraminidase-treated and untreated $\mathrm{RBCs}$ by cells of $P$. gingivalis 381 according to a turbidimetric method. The hemagglutination of enzyme-treated RBCs caused a more rapid and greater decrease of the $A_{542}$ after the start of the reaction than that of untreated RBCs.

The effect of various compounds on hemagglutination of neuraminidase-treated and untreated $\mathrm{RBCs}$ by $P$. gingivalis 381 was further studied by the turbidimetric method. The hemagglutination of both RBCs was unaffected by $5 \mathrm{mM}$ sugars or amino acids such as D-galactose, D-mannose, L-fucose, $N$-acetylglucosamine, $N$-acetylgalactosamine, NANA, glycine, L-alanine, L-valine, L-serine, L-arginine, L-lysine, L-proline, and L-leucine (data not shown). The results of hemagglutination-inhibition by some peptides are shown in Table 2. All arginine-containing peptides tested inhibited the hemagglutination of untreated RBCs. The inhibitory effect of these peptides except salmine was reduced by neuraminidase-treatment of

Table 2 Effect of neuraminidase-treatment of RBCs on hemagglutination inhibition with peptides

\begin{tabular}{|c|c|c|c|}
\hline \multirow{2}{*}{ Peptide } & \multirow{2}{*}{ Amino acid sequence } & \multicolumn{2}{|c|}{$\begin{array}{l}\text { Relative hemagglutinating } \\
\text { activity (\%) }\end{array}$} \\
\hline & & $\begin{array}{l}\text { Native } \\
\text { RBCs }\end{array}$ & $\begin{array}{c}\text { Neuraminidase- } \\
\text { treated RBCs }\end{array}$ \\
\hline Control & & 100 & 100 \\
\hline Salmine $(0.01 \mathrm{mM})$ & $\begin{array}{l}\text { Pro-Arg-Arg-Arg-Arg-Ser-Ser-Ser-Arg-Pro-Val-Arg- } \\
\text { Arg-Arg-Arg-Arg-Pro-Arg-Val-Ser-Arg-Arg-Agr- } \\
\text { Arg-Arg-Arg-Gly-Gly-Arg-Arg-Arg-Arg }\end{array}$ & 0 & 0 \\
\hline $\begin{array}{l}\text { cGMP dependent } \\
\text { inhibitor }(0.1 \mathrm{mM})\end{array}$ & Arg-Lys-Arg-Ala-Arg-Lys-Glu & 2 & 25 \\
\hline $\begin{array}{l}\text { Angiotensin I } \\
(0.1 \mathrm{mM})\end{array}$ & Asp-Arg-Val-Try-Ile-His-Pro-Phe-His-Leu & 3 & 95 \\
\hline $\begin{array}{l}\text { Angiotensin II } \\
(0.1 \mathrm{mM})\end{array}$ & Asp-Arg-Val-Try-Ile-His-Pro-Phe & 42 & 97 \\
\hline $\begin{array}{l}\text { Angiotensin III } \\
(0.1 \mathrm{mM})\end{array}$ & Arg-Val-Try-Ile-His-Pro-Phe & 16 & 68 \\
\hline $\begin{array}{l}\text { Bradykinin- } \\
\text { potentiator C } \\
(0.1 \mathrm{mM})\end{array}$ & Pyr-Gly-Leu-Pro-Pro-Gly-Pro-Pro-Ile-Pro-Pro & 100 & 100 \\
\hline
\end{tabular}

*The reaction mixture that did not contain the peptide was used as a control. The relative hemagglutinating activity was calculated on the basis of control by a turbidimetric assay. 
the RBCs. Bradykinin potentiator $\mathrm{C}$, which has no arginine residue, did not have an inhibitory effect.

For the native $\mathrm{RBC}$ s and $P$. gingivalis, zeta-potentials were $-18.3 \pm 3.10 \mathrm{mV}$ and $-9.80 \pm$ $1.30 \mathrm{mV}$ (mean \pm S.D.), respectively. The changes in hemagglutinating activity of $P$. gingivalis 381, zeta potential of RBCs and amount of NA. NA released during the course of neuraminidasetreatment are shown in Fig. 2. With increasing amounts of NANA released from the RBCs by neuraminidase, the zeta potential of the $R B C s$ approached zero and hemagglutination yielded higher activity.

\section{Discussion}

Studies on hemagglutination of human RBC by strains of $P$. gingivalis may contribute to knowledge about the adherence of these bac-

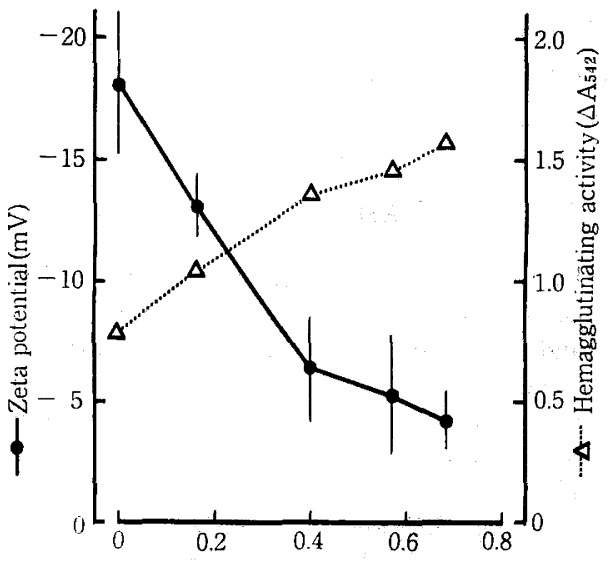

NANA released $\left(\mu \mathrm{g} / 5 \times 10^{7} \mathrm{RBCs}\right)$

Fig. 2 Effect of release of NANA from RBCs by the neuraminidase on zeta potential of RBCs and hemagglutinating activity of $P$. gingivalis 381 . teria to oral mucosal surfaces and possibly to the glycoprotein pellicle of teeth. In general, the mechanism of hemagglutination by bacteria involves specific and/or non-specific interactions between RBCs and bacteria. Oral bacteria such as $A$. viscosus, A. naeslundii ${ }^{3,4)}$ and Eikenella corrodens ${ }^{17}$ ) were found to have lectin-like proteins on their surfaces which bind to D-galactose or $N$-acetylgalactosamine-like receptors on the RBC surface, and their hemagglutination was enhanced by neuraminidase removal of terminal NANA. However, hemagglutination of both neuraminidase-treated and untreated RBCs by $P$. gingivalis was not inhibited by sugars including D-galactose and $N$-acetylgalactosamine (see the Results). Thus, bacterial lectins may not be involved in hemagglutination of $P$. gingivalis. Similar results were reported by Inoshita et al. ${ }^{18)}$, Grenier et al. ${ }^{19}$ and Okuda et al. ${ }^{20)}$. They also showedthat hemagglutination of $P$. gingivalis was inhibited by amino acids including L-arginine and L-lysine. However, in this study, hemagglutination was inhibited by arginine-containing peptides (Table 2) but not by the free amino acids tested (see the Results). Among arginine-containing peptides, salmine, which has many arginine residues, was the most potent inhibitor. Glycophorin $\mathrm{A}$, a major sialoglycoprotein of the RBC membrane, has a polypeptide chain containing arginine residues ${ }^{21)}$. Thus, it is hypothesized that hemagglutination by $P$. gingivalis would involve ligand-binding with arginine-containing peptides as receptors on the RBC surface.

Using the neuraminidase-treated $\mathrm{RBCs}$, arginine-containing peptides, except salmine, were found to be less inhibitory for hemagglutination by $P$. gingivalis. Although it is difficult to explain these findings, it is feasible that neuraminidase removal of NANA would influence non-specific forces including electrostatic and hydrophobic interactions. When the hydrophobicity of neuraminidase-treated and untreated RBCs was measured by hexadecane-adsorption test, no difference was found between them (data not shown). However, neuraminidase gradually increased agglutinability of RBCs as it reduced zeta-potential in proportion to the amount of NANA removed. Pollack ${ }^{22}$ ) proposed that the natural cohesive forces between RBCs in electrolyte solutions were opposed by the net negative surface charge of the cells. This net negative surface charge is largely due to the ionized carboxyl groups of NANA ${ }^{16)}$. The zeta-potential is the potential difference between the cell surface and the kinetically bound cloud of ions surrounding the RBC. 
With a decrease in zeta-potential, the thickness of the double-layer consisting of the negatively charged $\mathrm{RBC}$ as one layer and the diffuse cloud of cations as the other also may decrease. Therefore, the enhancing effect of neuraminidase could be explained as a result of the decrease in surface charge and, thus, zeta-potential.

\section{References}

1) Levine, M.J., Herzberg, M.C., Levine, M. S., Ellison, S.A., Stinson, M.W., Li, H.C. and van Dyke, T.: Specificity of salivarybacterial interaction: Role of terminal glycoproteins with Streptococcus sanguis and Streptococcus mitis, Infect. Immun., 19 ; 107-115, 1977.

2) McBride, B.C. and Gisslow, M.T.: Role of sialic acid in saliva-induced aggregation of Streptococcus sanguis, Infect. Immun. 18 ; 35-40, 1977.

3) Costello, A.H., Cisar, J.O., Kolenbrander, P.E. and Gabriel, O.: Neuraminidase-dependent hemagglutination of human erythrocytes by human strains of Actinomyces viscosus and Actinomyces naeslundii, Infect. Imm un., 26 ; 563-572, 1979.

4) Ellen, R.P., Fillery, E.D., Chan, K.H. and Grove, D.A.: Sialidase-enhanced lectin-like mechanism for Actinomyces viscosus and Actinomyces naeslundii hemagglutination, Infect. Immun., 27 ; 335-343, 1980.

5) Brennan, M.J., Cisar, J.O. and Sandberg, A.L.: A 160-kilodalton epithelial cell surface glycoprotein recognized by plant lectins that inhibit the adherence of Actinomyces naeslundii, Infect. Immun., $52 ; 840-845$, 1986.

6) Slots, J.: Importance of black-pigmented Bacteroides in human periodontal disease. In: Genco, R.J., Mergenhagen, S.E., eds. Host-parasite interactions in periodontal disease, Am. Soc. Microbiol., Washington DC, 1982, pp27-45.

7) Slots, J. and Gibbons, R.J.: Attachment of Bacteroides melaninogenicus subsp. asaccharolyticus to oral surfaces and its possible role in colonization of the mouth and of periodontal pockets, Infect. Immun., 19 ; 254264, 1978.

8) Rogers, R., Newbrun, E. and Tatevossian, A.: Neuraminidase activity in human dental plaque fluid, Archs Oral Biol., 24 ; 703705, 1979.

9) Perlitsh, M.J. and Glickman, I.: Salivary neuraminidase; I. The presence of neuraminidase in human saliva, J. Periodontol.,
37 ; 368-373, 1966.

10) Kitawaki, M., Iijima, K., Nakashizuka, T. and Hayakawa, T.: Neuraminidase activity in human crevicular fluid, J. Periodont. Res., $18 ; 318-320,1983$.

11) Nonaka, H., Ishikawa, Y., Otsuka, M., Toda, K., Sato, M. and Nakamura, R.: Purification and some properties of neuraminidase isolated from the culture medium of oral bacterium Streptococcus mitis ATCC 9811, J. Dent. Res., 62 ; 792-797, 1983.

12) Pinter, J.K., Hayashi, J.A. and Bahn, A. N. : Carbohydrate hydrolases of oral streptococci, Archs Oral Biol., 14 ; 735-744, 1969.

13) Takeshita, T., Hanioka, T., Tamagawa, H., Hsieh, C-C., Shizukuishi, S. and Yamamoto, Y.: Neuraminidase activity of some oral anaerobic bacteria, J. Osaka Univ. Dent. Sch., 23 ; 87-92, 1983.

14) Takeshita, T., Takagaki, M., Amano, A., Murakami, Y., Nagata, H. and Shizukuishi, S. : Purification and some properties of neuraminidase from the culture medium of Bacteroides loescheii, Oral Microbiol. Immunol., in press, 1991.

15) Uchida, T., Tsukada, Y. and Sugimori, T. : Distribution of neuraminidase in Arthrobac. ter and its purification by affinity chromatography, J. Biochem., 82 ; 1425-1433, 1977.

16) Eylar, E.H., Madoff, M.A., Brody, O.V. and Oncley, J.L.: The contribution of sialic acid to surface charge of the erythrocyte, J. Biol. Chem., 237 ; 1992-2000, 1962.

17) Ebisu, S. and Okada, H.: Agglutination of human erythrocytes by Eikenella corrodens, FEMS Microbiol. Lett., 18 ; 153-156, 1983.

18) Inoshita, E., Amano, A., Hanioka, $T$., $T_{2}$ magawa, H., Shizukuishi, $S$. and Tsunemitsu, A.: Isolation and some properties of exohemagglutinin from the culture medium of Bacteroides gingivalis 381, Infect. Immun., $52 ; 421-427,1986$.

19) Grenier, D. and Mayrand, D.: Functional characterization of extracellular vesicles produced by Bacteroides gingivalis, Infect. Immun., 55 ; 111-117, 1987.

20) Okuda, K., Yamamoto, A., Naito, Y., Takazoe, I., Slots, J. and Genco, R.J. : Purification and properties of hemagglutinin from 
culture supernatant of Bacteroides gingivalis, Infect. Immun., 54; 659-665, 1986.

21) Tomita, M. and Marchesi, V.T.: Aminoacid sequence and oligosaccharide attachment sites of human erythrocyte glycophorin,
Proc. Natl. Acad. Sci. USA. 72 ; 2964-2968, 1975.

22) Pollack, W.: Some physiochemical aspects of hemagglutination, Ann. NY. Acad. Sci., 127 ; 892-903, 1965. 